REV. 0

\title{
LONG-TERM SURVEILLANCE PLAN FOR THE \\ RIFle, COLORADO, DISPOSAL SITE
}

\section{RECEIVED \\ Nov $\cap 5$ rys \\ os $r$}

September 1996

\author{
Prepared for \\ U.S. Department of Energy \\ Environmental Restoration Division \\ UMTRA Project Team \\ Albuquerque, Now Mexico \\ Prepared by \\ Jacobs Engineering Group Inc. \\ Albuquerque, New Mexico
}




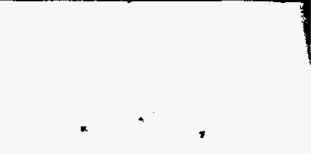




\section{DISCLAIMER}

Portions of this document may be illegible in electronic image products. Images are produced from the best available original document. 



\section{TABLE OF CONTENTS}

Section

Page

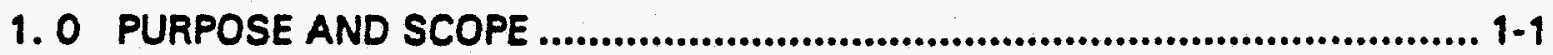

2. 0 FINAL SITE CONDITIONS.................................................................. 2-1

2.1 Site history.................................................................................... 2-1

2.2 General description of the site vicinity .................................................. 2-2

2.3 Disposal site description................................................................. 2-5

2.3.1 Site ownership and legal description ..................................... 2-5

2.3.2 Directions to the disposal site................................................ 2-6

2.3.3 Description of surface conditions ........................................... 2-6

2.3.4 Permanent site-surveillance features ........................................... 2-6

2.4 Disposal cell design ........................................................................ 2-8

2.5 Ground water characterization ......................................................... 2-9

2.5.1 Hydrogeology ........................................................................ 2-9

2.5.2 Background ground water quality........................................... 2-11

2.5.3 Hazardous constituents .......................................................... 2-12

2.6 Ground water protection ............................................................ 2-13

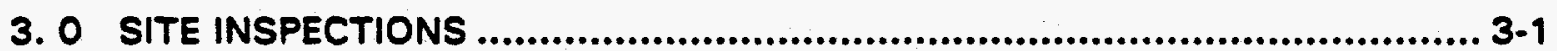

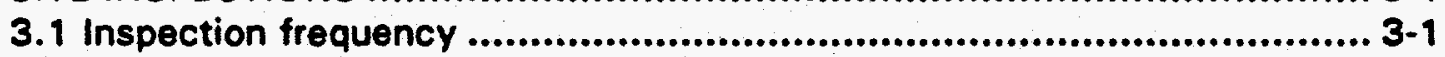

3.2 Inspection team ................................................................................ 3-1

3.3 Site inspection procedures ................................................................. 3-1

3.4 Follow-Up inspections..................................................................

3.5 Quality assurance............................................................................... 3-4

3.6 Site inspection documentation ....................................................... 3-4

3.6.1 Site inspection checklist ........................................................ 3-4

3.6.2 Site inspection maps .......................................................... 3.4

3.6.3 Site inspection photographs .................................................. 3-5

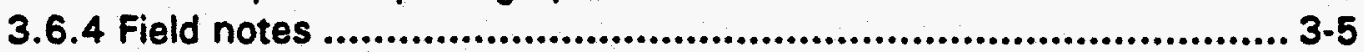

3.6.5 Site inspection report ............................................................... 3-5

4. 0 GROUND WATER MONITORING .......................................................... 4-1

4.1 Ground water monitoring plan............................................................ 4-1

5. 0 CUSTODIAL MAINTENANCE AND REPAIR............................................ 5-1

6. 0 CORRECTIVE ACTION ...................................................................... 6-1

7. 0 EMERGENCY NOTIFICATION AND RESPONSE ..................................... 7-1

8. 0 RECORD KEEPING AND REPORTING .............................................. 8-1

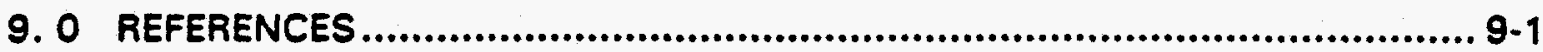


TABLE OF CONTENTS (Concluded)
ATTACHMENT 1 SITE REAL ESTATE INFORMATION
ATTACHMENT 2 AGENCY NOTIFICATION AGREEMENTS
APPENDIX A
MONITOR WELL CLOSURE PLAN

\section{LIST OF FIGURES}

\section{Finure}

Pane

2.1 Location map, Rifle, Colorado site

$2-3$

2.2 Vicinity map, Rifle, Colorado, disposal site

3.1 Steps for follow-up inspections, custodial maintenance, and corrective action...

\section{LIST OF PLATES}

Piate

1 Disposal site baseline map, Rifle, Colorado, site

\section{LIST OF TABLES}

Table

2.1 Locations of permanent surveillance features, Rifle,

Colorado, disposal site

2.2 Completion intervals and ground water levels in monitor wells, Estes Gulch disposal site 


\title{
LIST OF ACRONYMS
}

\section{Acronym Definition}

$\begin{array}{ll}\text { BLM } & \text { Bureau of Land Management } \\ \text { DOE } & \text { U.S. Department of Energy } \\ \text { EA } & \text { environmental assessment } \\ \text { EPA } & \text { U.S. Environmental Protection Agency } \\ \text { LTSP } & \text { long-term surveillance plan } \\ \text { MCL } & \text { maximum concentration limit } \\ \text { NGVD } & \text { National Geodetic Vertical Datum } \\ \text { NRC } & \text { U.S. Nuclear Regulatory Commission } \\ \text { POC } & \text { point of compliance } \\ \text { RAP } & \text { remedial action plan } \\ \text { UMTRA } & \text { Uranium Mill Tailings Remedial Action } \\ \text { UMTRCA } & \text { Uranium Mill Tailings Radiation Control Act }\end{array}$

\section{DISCLAIMER}

\begin{abstract}
This report was prepared as an account of work sponsored by an agency of the United States Government. Neither the United States Government nor any agency thereof, nor any of their employees, makes any warranty, express or implied, or assumes any legal liability or responsibility for the accuracy, completeness, or usefulness of any information, apparatus, product, or process disclosed, or represents that its use would not infringe privately owned rights. Reference herein to any specific commercial product, process, or service by trade name, trademark, manufacturer, or otherwise does not necessarily constitute or imply its endorsement, recommendation, or favoring by the United States Government or any agency thereof. The views and opinions of authors expressed herein do not necessarily state or reflect those of the United States Government or any agency thereof.
\end{abstract}


CHANGE HISTORY

\begin{tabular}{c|c|c}
\hline Document version & Date & \multicolumn{1}{c}{ Pages/comments } \\
\hline Rev. 1, Ver. 1 & & Initial version with editorial changes. \\
\hline
\end{tabular}





\subsection{PURPOSE AND SCOPE}

This long-term surveillance plan (LTSP) describes the U.S. Department of Energy's (DOE) long-term care program for the Uranium Mill Tailings Remedial Action (UMTRA) Project Estes Guich disposal site in Garfield County, Colorado.

The U.S. Environmental Protection Agency (EPA) has developed regulations for the issuance of a general license by the U.S. Nuclear Regulatory Commission (NRC) for the custody and long-term care of UMTRA Project disposal sites in 10 CFR Part 40. The purpose of this general license is to ensure that the UMTRA Project disposal sites will be cared for in a manner that protects the public health and safety and the environment. For each disposal site to be licensed, the NRC requires the DOE to submit a site-specific LTSP. The DOE prepared this LTSP to meet this requirement for the Estes Gulch disposal site. The general license becomes effective when the NRC concurs with the DOE's determination of completion of remedial action for the Estes Gulch site and the NRC formally accepts this LTSP.

This LTSP describes the long-term surveillance program the DOE will implement to ensure that the Estes Gulch disposal site performs as designed. The program is based on site inspections to identify threats to disposal cell integrity. The LTSP is based on the UMTRA Project long-term surveillance program guidance (DOE, 1996) and meets the requirements of 10 CFR $\$ 40.27(\mathrm{~b})$ and 40 CFR $\$ 192.03$.

This LTSP includes Appendix A, "Closure Plan for Monitoring Wells, Estes Gulch Disposal Cell." The standpipe closure activities are not discussed within the text of the LTSP. 


\subsection{FINAL SITE CONDITIONS}

Remedial action at the former uranium processing sites in Rifle, Colorado, consisted of excavating and relocating the residual radioactive materials to the Estes Gulch disposal site. The DOE constructed a disposal cell to control the residual radioactive material in accordance with 40 CFR Part 192. The Estes Gulch disposal site will be fenced, and its perimeter is marked with warning signs. The site completion report will contain a detailed description of the final site conditions.

\subsection{SITE HISTORY}

There are two former processing sites near Rifle, Colorado, Old Rifle and New Rifle, which are approximately $\mathbf{2}$ miles (mi) (3 kilometers ( $\mathrm{km}$ ) apart. Both are located on the floodplain of the Colorado River valley and are north of the Colorado River. Old Rifle is just east of the city limits of Rifle, in Garfield County, Colorado. New Rifle is west of Rifle.

Both sites were once owned by Union Carbide Corporation, but are now owned by the State of Colorado The Old Rifle mill was built by the Standard Chemical Company in 1924 and in 1928 was bought by the United States Vanadium Corporation lan eventual subsidiary of the Union Carbide Corporation). The mill operated from 1924 to 1932, and again from 1942 to 1946 for recovery of vanadium. In 1946, uranium processing was added to the vanadium recovery circuit and recovery of both vanadium and uranium continued until 1958. In 1958, operations were transferred to the New Rifle mill and the Old Rifle mill was shut-down.

About 761,000 tons (685,000 tonnes) of ore from the nearby Meeker and Rifle Creek mines, as well as ore from the Uravan Mineral belt, were processed at the Old Rifle mill. Tailings and spent processing solutions were deposited at the site. About 411,000 tons (373,000 tonnes) of these tailings were later reprocessed at the New Rifle mill and deposited there. However, about 350,000 tons (317,000 tonnes) of tailings (approximately 259,000 cubic yards [cy] [197,000 cubic meters]) remained at Old Rifle. In 1967, Union Carbide moved the southern edge of this tailings pile away from the Colorado River and partially stabilized the pile with a 6-inch (15-centimeter [cm]) cover of earth seeded with grasses.

In July, 1958, operations began at the New Rifle mill, which produced both uranium and vanadium until December 1972. After 1972, only vanadium was produced and all milling operations ceased in 1981. In addition to tailings from the Old Rifle site, uranium ores and upgrader products were processed at the New Rifle mill. A total of 2.7 million tons (2.4 million tonnes) of tailings, ores, and upgrader products were processed.

Upgrader products came from other Union Carbide mills at Slick Rock, Colorado and Green River, Utah. Upgrader products from Slick Rock were dried fines, dried slime concentrates, green sludge, and uranium-bearing chemical precipitates. The Green River upgrader products consisted of dried slimes and asphaltic uranium-bearing concentrates. Uranium bearing lignite ash from Belfield, North Dakota was also supplied to the New Rifle mill. Spent processing solutions and about 2 million cy ( 1.5 million cubic meters) of tailings 
were deposited at the site. Union Carbide partially stabilized the New Rifle pile with mulch, fertilizer, and native grasses.

At the Old Rifle mill, a salt roasting process was initially used to recover vanadium. Water, sodium chloride, and sulfuric acid were used in this process. When uranium processing was added to the vanadium recovery circuit in 1946, additional reagents used were hydrochloric acid, sodium hypochlorate, sodium carbonate, ferric iron sulfate, ammonia, and ammonium chloride.

The New Rifle mill used a solvent extraction method to recover uranium. Reagents used in the process included water, sodium chloride, sulfuric and hydrochloric acid, kerosene, di(2ethylhexyl) phosphoric acid, sodium hypochlorate, sodium carbonate, sodium hydroxide, and ammonia.

The Uranium Mill Tailings Radiation Control Act (UMTRCA) of 1978 (42 USC $\$ 7901$ et seq.) gave the DOE authority to perform remedial action at both Rifle sites. The DOE evaluated the environmental impacts associated with site remedial action in an environmental assessment (EA) (DOE, 1987). The NRC and the state of Colorado concurred with the DOE's remedial action plan (RAP) (DOE, 1992) to comply with the requirements of 40 CFR Part 192, Subparts A-C.

The DOE began constructing the Estes Gulch disposal cell in 1993. During 1994 and 1995, the DOE relocated uranium mill tailings and other residual radioactive materials (such as contaminated mill buildings and associated debris, windblown materials, and about $24,000 \mathrm{cy}[18,400$ cubic meters] of vicinity property materials) and placed them in the disposal cell. Construction of the disposal cell will be completed in 1996 with placement of a radon/infiltration barrier and frost and erosion protection layers.

The DOE will prepare a completion report documenting compliance with the RAP and the site as-built conditions. In addition, the DOE will prepare a final audit report and certification summary and submit it, along with the completion report, to the NRC for concurrence. Concurrence from the NRC on the completion report will be included in the permanent site file:

\subsection{GENERAL DESCRIPTION OF THE SITE VICINITY}

The Rifle (Estes Gulch) disposal site is in Garfield County in southwest Colorado on the western slope of the Rocky Mountains (Figure 2.1). The site is approximately $6 \mathrm{mi}$ $(10 \mathrm{~km})$ north of the town of Rifle, Colorado, in Township 5 South, Range 93 west, Section 14 (Figure 2.2). This section provides a brief description of the site vicinity. Detailed descriptions can be found in the site EA (DOE, 1987) and the RAP (DOE, 1992).

The general climatic regime in the vicinity of the Estes Gulch disposal site is semiarid. North of Estes Gulch at significantly higher elevations, precipitation is much heavier. The area is characterized by low humidity, frequent sunny days, and large diurnal and seasonal 


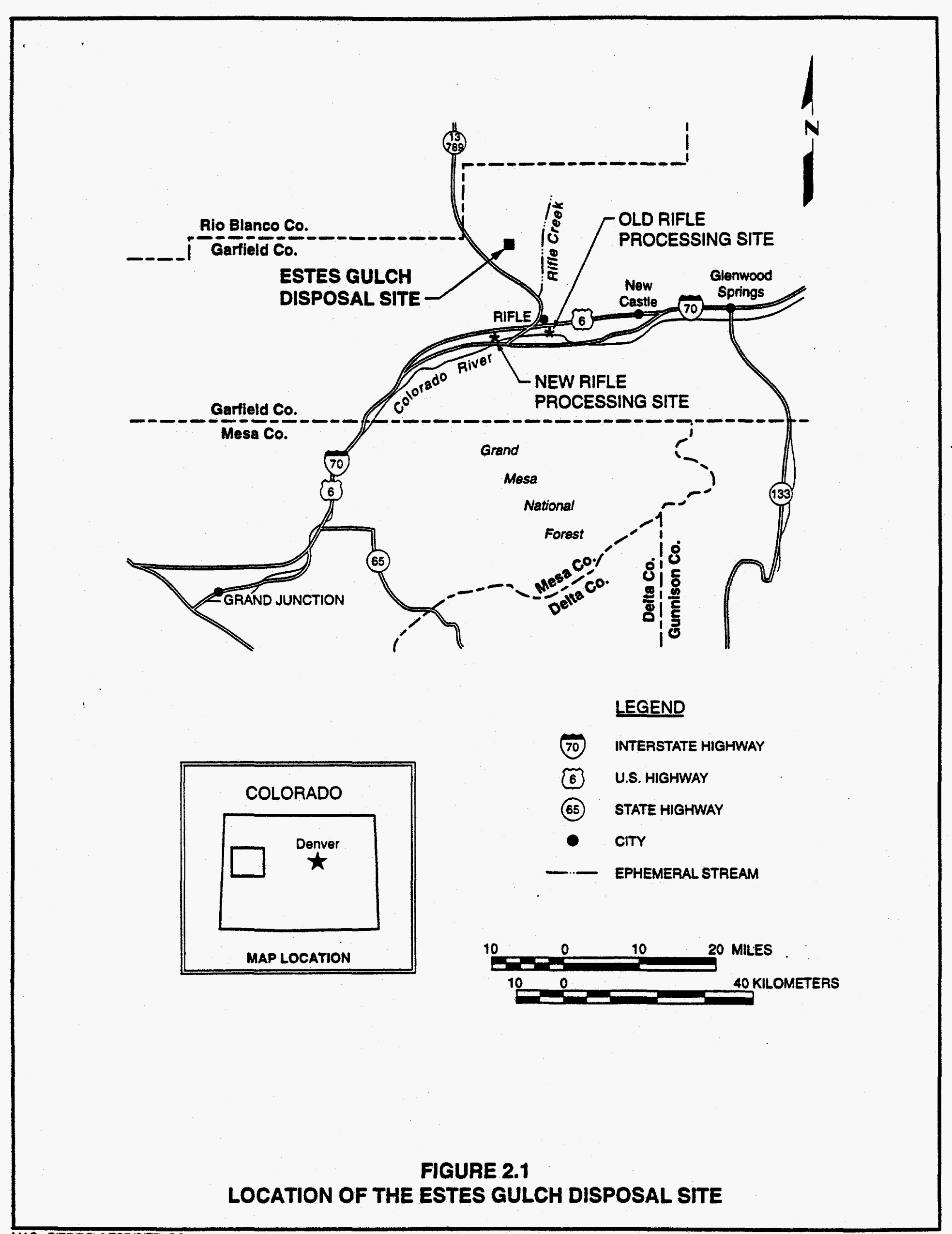




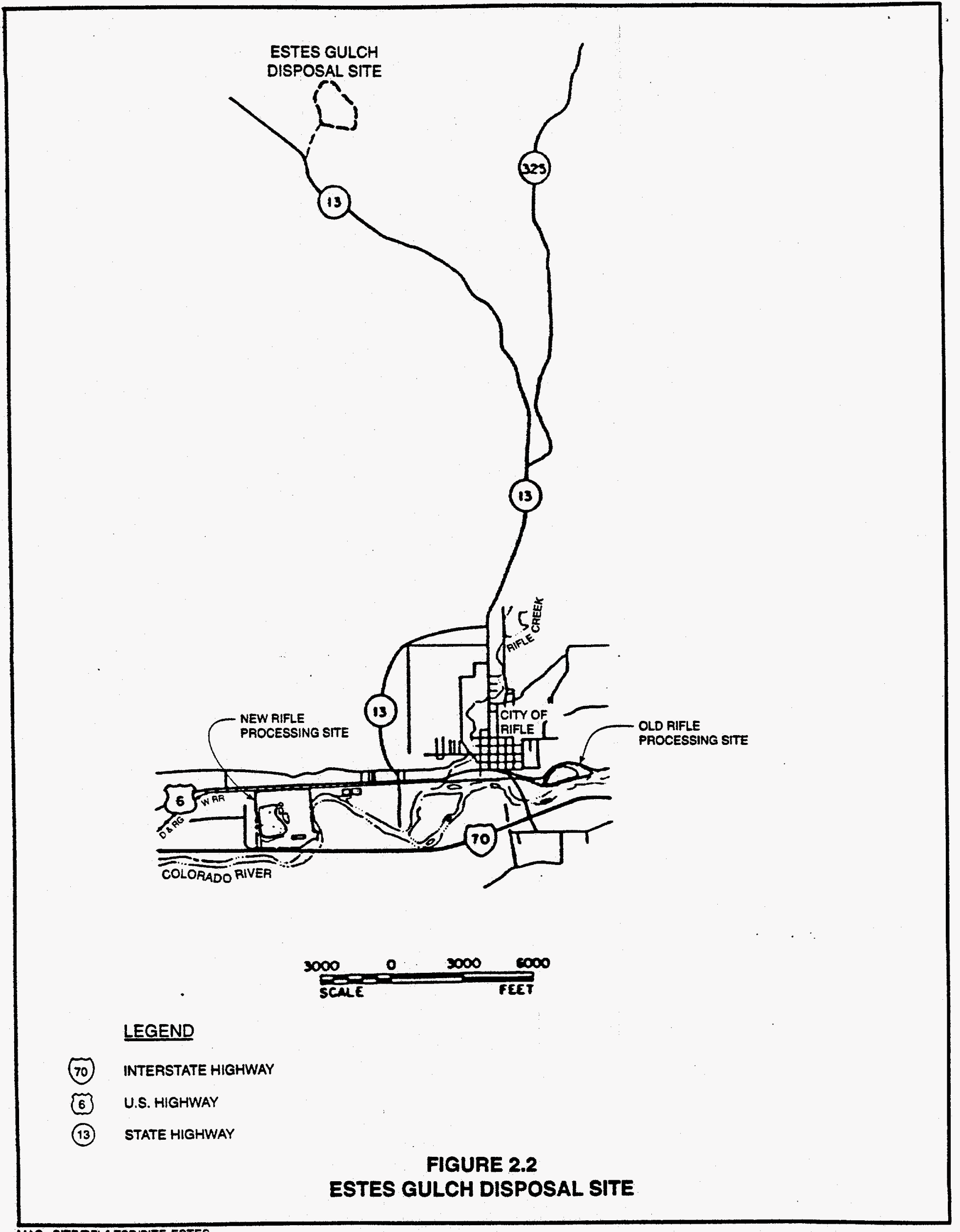


temperature ranges. The average annual precipitation is 11 inches (280 millimeters (mm]) and the average temperatures range from $23^{\circ}$ to $71^{\circ} \mathrm{F}\left(-5\right.$ to $22^{\circ} \mathrm{C}$ (Yeend, 1969). Snowfall averages 37 inches $(940 \mathrm{~mm})$ a year. The highest monthly rainfall usually occurs during July and August, while the least rainfall occurs from April through June. Summer rainfalls occur as intense, scattered thunderstorms. Very little direct information exists regarding the frequency, duration, and intensities of winds in the Estes Gulch disposal site area. At the Garfield County Airport, south of Rifle, winds are strongest and most frequent from the north, southwest, and south (FBDU, 1981). Along the Colorado River Valley, winds are channeled in an east-west direction up and down the valley.

The Estes Gulch disposal site ranges from about 5960 to 6200 feet $(\mathrm{ft})(1820$ to 1890 meters (m]) above mean sea level. The Grand Hogback rises to an elevation of about $8000 \mathrm{ft}(2440 \mathrm{~m})$ north of the site. To the south, the dissected pediment surfaces drop down to the alluvial valley of Rifle Creek at an elevation of about $5500 \mathrm{ft}(1680 \mathrm{~m})$.

The Estes Gulch disposal site is at the head of a small drainage basin on a dissected pediment and alluvial fan surface sloping to the southwest toward Government Creek from the foot of the Grand Hogback monocline.

The only off-site water that could have affected the integrity of the cell previously came from a 20-acre (ac) watershed north of the cell. Runoff from about six ac of the uppermost part of this watershed was diverted away from the disposal cell by means of an interceptor ditch. The other 14 ac of the watershed between the interceptor ditch and the cell were graded and provided with an erosion resistant cover. The graded area has a slight crown to shed some runoff away from the cell and onto the adjacent ground. Precipitation falling on top of the cell will drain to a toe ditch at the south end and will discharge eastward into Estes Gulch (DOE, 1992).

There is little potential for future natural resource development in the immediate site vicinity. There are no ground water users in the immediate vicinity of the Estes Gulch disposal site.

\subsection{DISPOSAL SITE DESCRIPTION}

This section provides a brief description of the disposal site; detailed descriptions can be found in the site RAP (DOE, 1992b) and completion report (MK-F, 1996).

\subsubsection{Site ownership and legal description}

The government currently owns the Estes Gulch disposal site and most of the surrounding area. The Bureau of Land Management (BLM) permanently transferred administration of public land to the DOE in August 1991 for use as the Estes Gulch disposal site. The BLM administers the adjacent surrounding lands. Attachment 1 provides a legal description of the disposal site. Plate 1 shows the final site boundary and identifies ownership of the site and surrounding areas at the time of licensing. 


\subsubsection{Directions to the disposal site}

The Estes Gulch disposal site can be reached by automobile via paved roads (Figure 2.2) as described in the following directions.

1. From Rifle, Colorado, at the intersection of Highway 6 \& 24 and Highway 13, take Highway 13 north about $6 \mathrm{mi}(10 \mathrm{~km})$.

2. Turn right (northeast) onto the dirt road, which is about $1.5 \mathrm{mi}(2 \mathrm{~km})$ past the intersection of Highway 13 and the Highway 13 bypass. Follow this paved road about a mile to the disposal site.

Entry to the disposal site is restricted by a fence at the site entrance. The south access gate is kept locked and the key needed to enter the site may be obtained from the Grand Junction Project Office.

\subsubsection{Description of surface conditions}

The Estes Guich disposal site is located on approximately 205 acres (ac) (83 hectares [ha]) of land (Plate 1). The completion report (to be written by MK-F), will contain a detailed description of the final site conditions, including the results of the final site topographic survey.

The final site grading has all areas contoured to promote drainage away from the disposal cell. A mix of grasses was used to revegetate all disturbed areas of the disposal site not covered by riprap.

At the completion of remedial action, the DOE documented final disposal site conditions with site maps, as-built drawings, and ground and aerial photographs.

\subsubsection{Permanent site-surveillance features}

Survey and boundary monuments, site markers, and warning signs are the permanent longterm surveillance features of the Estes Gulch disposal site. The disposal site has no ground water monitor wells. Plate 1 shows the locations of these features and Table 2.1 provides their survey grid coordinates. Typical construction and installation specifications for these features are shown in the long-term surveillance guidance (DOE, 1996) and subcontract documents (DOE, 1996b).

Three survey monuments establish permanent horizontal control based on the Colorado State Plane Coordinate System (Central Zone) and are referenced to the Project Survey Control Points. These control points are shown on Plate 1 and their location coordinates are given in Table 2.1. The three permanent survey monuments (SM-1, SM-2, and SM-3) are Berntsen RT-1 markers set in concrete, with the monument about 4 inches $(10 \mathrm{~cm}$ ) above ground level. Magnets in the markers permit easier detection if the markers become buried over time. The survey monument identification number is stamped on the top of the metal cap. 
Table 2.1 Locations of permanent surveillance features, Rifle, Colorado, disposal site

\begin{tabular}{|c|c|c|}
\hline FEATURE & \multicolumn{2}{|c|}{ LOCATION COORDINATES } \\
\hline $\begin{array}{l}\text { SURVEY MONUMENTS } \\
\text { SM-1 } \\
\text { SM-2 } \\
\text { SM-3 }\end{array}$ & $\begin{array}{l}\text { N } 56,000 \\
\text { N } 56,500 \\
\text { N } 59,600\end{array}$ & $\begin{array}{l}E 53,400 \\
E 52,100 \\
E 52,600\end{array}$ \\
\hline $\begin{array}{c}\text { SITE MARKERS } \\
\text { SMK-1 } \\
\text { SMK-2 }\end{array}$ & $\begin{array}{l}\text { N } 56,000 \\
\text { N } 57,200\end{array}$ & $\begin{array}{l}\text { E } 53,550 \\
\text { E } 52,550\end{array}$ \\
\hline $\begin{array}{l}\text { BOUNDARY MONUMENTS } \\
\text { BM-1 } \\
\text { BM-2 } \\
\text { BM-3 } \\
\text { BM-4 } \\
\text { BM-5 } \\
\text { BM-6 } \\
\text { BM-7 } \\
\text { BM-10 } \\
\text { BM-11 } \\
\text { BM-12 } \\
\text { BM-14 } \\
\text { BM-15 } \\
\text { BM-16 } \\
\text { BM-18 } \\
\text { BM-19 }\end{array}$ & 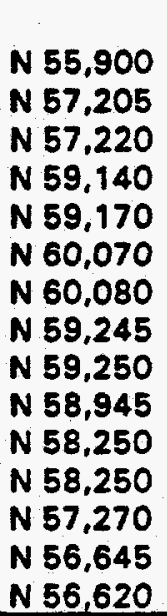 & $\begin{array}{l}\text { E } 54,270 \\
\text { E } 54,280 \\
\text { E } 53,655 \\
\text { E } 53,680 \\
\text { E } 54,000 \\
\text { E } 53,985 \\
\text { E } 53,360 \\
\text { E } 52,350 \\
\text { E } 52,050 \\
\text { E } 52,045 \\
\text { E } 51,690 \\
\text { E } 51,385 \\
\text { E } 51,360 \\
\text { E } 51,185 \\
\text { E } 52,010\end{array}$ \\
\hline
\end{tabular}

- Coordinates in feet based on Project Survey Control Points

CP.13, N 58634.94, E 54353.21

CP-15, N 59208.41, E 52222.98

CP-19, N 59856.50, E 53526.86

Twenty site boundary corners define the final site boundary. Of these, fifteen are marked with boundary monuments. Five are not marked with monuments because of extremely difficult terrain. The boundary monuments are Berntsen A-1 markers set in concrete. Of these, standard boundary monuments are used at five locations. The standard monuments are reinforced concrete that extend to a depth of $6 \mathrm{ft}(1.8 \mathrm{~m})$ or to hard rock. The marker extends about 1 inch $(25 \mathrm{~mm})$ above the ground surface. The remaining ten monuments have been modified for area conditions and are concrete placed to a minimum depth of $3 \mathrm{ft}$ $(1 \mathrm{~m})$ or 6 inches $(15 \mathrm{~cm})$ below rock. In these, the marker extends a minimum of 12 inches $(0.3 \mathrm{~m})$ above the ground surface. Magnets in the A-1 monuments allow easier detection if they become buried. The boundary monument identification number is stamped on the top of the metal cap.

Two unpolished granite markers with an incised message identify the Estes Gulch disposal site. The message includes a drawing showing the general location of the stabilized disposal cell within the site boundaries, the date of closure (not evailable), the weight of the tailings (not available), and the amount of radioactivity (not available). Site marker SMK-1, near the south access gate to the site, is set in reinforced concrete that extends 6 
ft $(1.8 \mathrm{~m})$ below the ground surface. Site marker SMK-2, at the crest of the disposal cell, is set in reinforced concrete that extends to the top of the frost protection barrier.

The DOE has posted property use warning signs $(18$ inches $[460 \mathrm{~mm}$ ] by 24 inches [610 $\mathrm{mml}$ around the disposal site perimeter at approximately $200-\mathrm{ft}(60-\mathrm{m})$ intervals along the south side of the site and approximately 500-ft $(150-\mathrm{m})$ intervals elsewhere. The site entrance sign is at the south access gate to the disposal site near site marker SMK-1. The entrance sign also displays the DOE 24-hour phone number to call concerning the site. In addition to the entrance sign, 60 perimeter warning signs are located about $5 \mathrm{ft}(1.5 \mathrm{~m})$ inside the site fence. The warning signs are mounted on steel posts with the tops of the signs about $6 \mathrm{ft}(1.8 \mathrm{~m})$ above the ground surface. The sign posts are embedded in concrete to a depth of about $3 \mathrm{ft}(1 \mathrm{~m})$ below the ground surface.

\subsection{DISPOSAL CELL DESIGN}

The 71-ac (29-ha) disposal cell is located on a gently sloping pediment between the Grand Hogback and the Government Creek Valley, a tributary to Rifle Creek and the Colorado River. The area of the disposal cell is not subject to any significant hazard from slope failure processes such as landslides, debris flows, mud flows, and rock falls. The geomorphic processes posing a potential hazard to the stabilized disposal cell are ephemeral drainage channel changes, low-gradient slope erosion, and wind erosion; however, these processes are not reasonably expected to affect the disposal cell within the next 100 years, or in any case for at least 200 years.

The disposal cell is constructed partially below grade and rises above the surrounding terrain to a maximum elevation of about $6090 \mathrm{ft}(1856 \mathrm{~m})$ above NGVD. The disposal cell contains approximately $2,756,000$ cubic yards $(2,107,000$ cubic meters) of relocated tailings and other residual radioactive materials, primarily contaminated soils and demolition debris. The disposal cell is capped with an $11-\mathrm{ft}(3.35-\mathrm{m})$-thick multiple-component cover.

An 1.5-ft $(0.45-\mathrm{m})$-thick radon/infiltration barrier is placed over the contaminated materials. This barrier is constructed of on site clay soils and is designed to reduce the radon-222 flux from the disposal cell to less than 20 picocuries per square meter per second and minimize water infiltration in to the tailings. A $0.5-\mathrm{ft}(0.15-\mathrm{m})$-thick, coarse-grained filter layer is placed on top of the radon/infiltration barrier to provide a capillary break and promote drainage of infiltrating water away from the radon barrier. A 7.5-ft $(2.3-\mathrm{m})$-thick layer of compacted soil lies on top of the filter layer to insulate the radon/infiltration barrier and keep it from being adversely affected by freezing and thawing cycles. The topslopes and sideslopes of the disposal cell are capped with rock riprap to protect against wind and water erosion and prevent damage to the underlying radon/infiltration barrier.

The erosion protection layer is $1-\mathrm{ft}(0.3-\mathrm{m})$ thick. A $0.5-\mathrm{ft}(0.15-\mathrm{m})$-thick bedding layer is between the riprap and the frost protection layer to prevent damage to the layer from rocks and loss of the soil from runoff water. The maximum grade is 6.5 percent on the topslopes and 20 percent on the sideslopes. These grades, in conjunction with the bedding layer, will allow excess surface water to run off the disposal cell and be conveyed to adjacent site grades in a manner that minimized the risk of significant erosion. The 
components of both the topslope and sideslope covers are intended to minimize the potential for deep percolation of precipitation into the residual radioactive material.

At the toe of the disposal cell there is a riprap apron and toe ditch to carry water away from the cell and to provide erosion protection from gullying. A rock-lined interceptor ditch abuts the upslope portion of the disposal cell to divert surface flow away from the cell.

Detailed engineering drawings of the disposal cell are in the site completion report.

\subsection{GROUND WATER CHARACTERIZATION}

This section briefly describes the hydrogeologic units and background ground water quality at the Estes Gulch disposal site and identifies the constituents of concern at the site. More detail on ground water characterization of the site is found in the Rifle RAP (DOE, 1992b).

\subsubsection{Hydrogeology}

The hydrogeology of the Estes Gulch disposal site was characterized during preparation of the RAP (DOE, 1992b). The Estes Gulch disposal site is underlain by the Wasatch Formation, which consists of at least $3800 \mathrm{ft}(1160 \mathrm{~m})$ of siltstones, shales and finegrained sandstones. The Mesa Verde Group (Ohio Creek and Williams Fork Formations) underlies the Wasatch Formation, and is the uppermost aquifer beneath the disposal cell. The Williams Fork Formation of the Mesa Verde Group is approximately $4500 \mathrm{ft}(1370 \mathrm{~m})$ thick, and consists of light-brown to white sandstones, gray to black shale, and coal beds (Tweto et al, 1978). The resistant beds of the formation comprise the Grand Hogback north of the disposal site. The thin Ohio Creek Formation is considered by some authors to be the uppermost member of the Mesa Verde Group (and Williams Fork Formation). However, the kaolinitic Ohio Creek unit is less than $100 \mathrm{ft}(30 \mathrm{~m})$ thick near

Estes Gulch and is not known to be a regional aquifer in the area. Near the Estes Gulch disposal site, the Ohio Creek unit contains a high percentage of clay and appears to be quite impermeable.

Beneath the disposal site, bedding planes in the Wasatch Formation dip approximately 65 to 75 degrees to the southwest. This dip decreases abruptly to 10 to 20 degrees 500 to $800 \mathrm{ft}(150$ to $240 \mathrm{~m})$ downslope of the proposed toe of the pile. This abrupt change in dip occurs olong a fault which parallels the Grand Hogback. The fault is filled with clay gouge and does not appear to be a significant ground water transport pathway. Analysis of well recovery data from well 702 completed in the fault zone vielded a hydraulic conductivity of $1 \times 10^{-9} \mathrm{~cm} / \mathrm{s}$ (Calculation No. RFL 09-89-14-02a). Exploratory drilling conducted during characterization of the Estes Gulch disposal site encountered other minor faults paralleling the bedding planes and occurring randomly in the steeply dipping strata beneath the site. These faults are also filled with clay gouge. Closely spaced fractures sometimes occur near these minor faults, becoming widely spaced within a few feet of the faults. 
The Wasatch Formation is an aquitard, and does not contain significant quantities of ground water (Wright Water Engineers, 1979; Giles, 1980: Coffin et al, 1968; and Coffin et al, 1971). The limited ground water in the Wasatch Formation beneath the site flows through fractures and joints along the strike of the beds. Localized recharge to the bedrock occurs through weathered zones and fractures, and in areas where more permeable beds outcrop at the surface. Recharge percolates down to limited zones of saturation, and ground water then slowly flows along the strike of the nearly vertical beds. Because ground water saturation is localized and because ground water levels never reached hydrostatic equilibrium within completed wells, the potentiometric surface and potentiometric gradient cannot be defined in the vicinity of the disposal cell.

The DOE installed a total of 13 monitoring wells at the Estes Gulch disposal site prior to disposal cell construction. These wells are no longer sampled and are not point of compliance (POCl wells. A majority of the wells have been abandoned. Table 2.2 provides construction information for the monitoring wells.

In 1986, the DOE installed ten monitor wells at the Estes Gulch site (monitor wells 952 through 969. Depths of the wells ranged from 60 to $301 \mathrm{ft}(18$ to $92 \mathrm{~m})$. Nine of the wells are dry. Water was encountered in the deepest well (well 963) at a depth of $270 \mathrm{ft}$ $(82 \mathrm{~m})$ below the ground surface. The water level then slowly rose to a depth of $150 \mathrm{ft}$ $(46 \mathrm{~m})$ below ground surface when last measured. In 1988, the DOE installed three additional wells (wells 701, 702, and 703) completed to depths of 500 to $545 \mathrm{ft}(150$ to $165 \mathrm{~m})$. Monitor well 701 was located south of the fault (mentioned above). All three wells showed little or no water at completion. However, water levels began to rise in wells 701, 702, and 703 following completion. When last measured in March 1992, ground water levels ranged from 274 to $434 \mathrm{ft}$ ( 84 to $132 \mathrm{~m}$ ) below ground surface in the three wells.

Table 2.2. Completion intervals and ground water levels in monitor wells, Estes Gulch disposal site

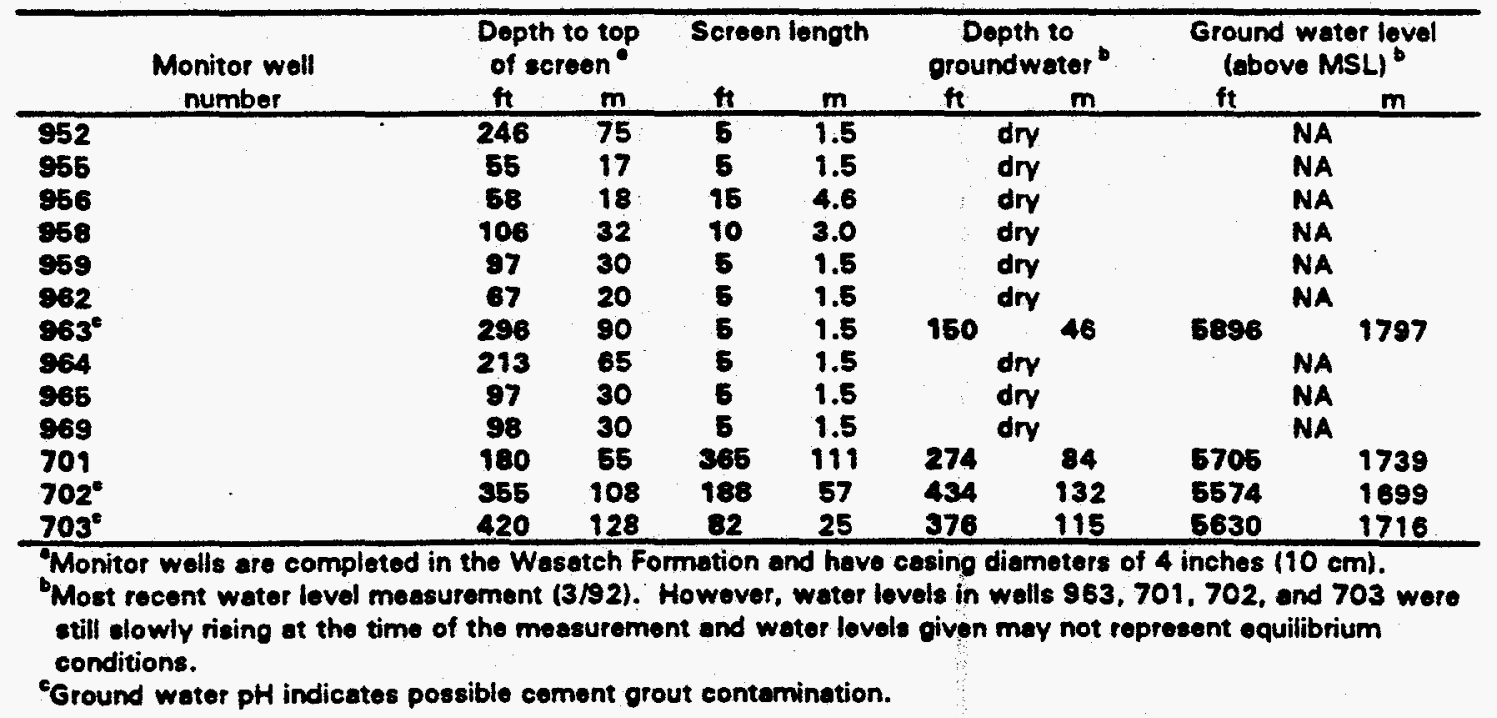


Ground water levels in the four wells that produced water did not appear to reach hydrostatic equilibrium during the four-year period of sampling, reflecting the very low permeability of the bedrock beneath the disposal site. After periods of more than two years, water level elevations differed by $75 \mathrm{ft}(23 \mathrm{~m})$ or more between completed wells and showed no defined piezometric surface.

Several phases of permeability testing of the Wasatch Formation bedrock at the Estes Gulch disposal site have been conducted. These include field studies by the Technical Assistance Contractor (TACl, MK-ES with support by Morrison Knudson-Ferguson, and Daniel B. Stephens \& Associates. Laboratory permeability testing was conducted by the University of Arizona, Lambert and Associates, and Herzog Associates. A summary of testing results is presented below.

The TAC estimated a mean hydraulic conductivity of $7 \times 10^{-10} \mathrm{~cm} / \mathrm{s}$ for the saturated deep Wasatch Formation using water level recovery data (Calculation RFLO9-89-14-02-9). However, hydrostatic equilibrium in these wells which varied in depth from 300 to $440 \mathrm{ft}$ $(91$ to $134 \mathrm{~m})$ in depth was never achieved.

In order to improve the estimates of permeability of the sandstones and siltstones at the bottom of the excavation for the disposal cell a number of short-. intermediate-, and longterm infiltrometer tests were conducted in 1993. This testing defined the saturated vertical permeability of sandstones at the low portion of the disposal cell and the saturated vertical permeability of siltstone in the cell foundation. The geometric mean of the low portion of the disposal cell was found to be $4 \times 10^{-7}$ centimeters per second $(\mathrm{cm} / \mathrm{s})$. The permeability of the siltstone was determined to range from $7 \times 10^{-8} \mathrm{~cm} / \mathrm{s}$ to $3 \times 10^{-6} \mathrm{~cm} / \mathrm{s}$.

\subsubsection{Background ground water quality}

The DOE installed 13 monitor wells at the Estes Gulch disposal site prior to disposal cell construction. Four wells $(963,701,702$, and 703), which were completed at deeper levels, produced sufficient water for sampling. Ground water quality sampling of these wells was conducted at the Estes Gulch disposal site from 1986 through 1992.

The pH values in ground water sampled from monitoring wells completed in the Wasatch Formation beneath the site range from 7.3 to 12.8. Samples from three of the four wells (Table 2.2) may be cement-grout contaminated, with pH values ranging from 10.9 to 12.8 . However, it is also possible that this pH is natural (DOE, 1992).

Background water quality is difficult to characterize for the Wasatch Formation because of slow recharge to the wells, the possibility of grout contamination in three wells, and because the chemistry of water sampled from all wells varied with changes in water levels. This is especially true of trace metals, such as selenium, cadmium and radium, which were at high levels (greater than maximum concentration limits [MCL]) during the first sampling rounds, but which decreased to levels below detection or MCLs as water levels in the wells increased. 
Well 963, which has a 5-ft $(1.5-\mathrm{m})$ screened interval, produced very little water and water quality varied from one sampling round to the next. This, in conjunction with evidence for grout contamination, indicates that samples from this well may not reflect ground water quality in the Wasatch. By contrast, major element concentrations were relatively constant during the entire four-year period of sampling of wells 701, 702, and 703. These three wells screen large intervals of the Wasatch formation (Table 2.2). Thus, the chemistry of ground water from these three wells is likely typical of Wasatch Formation ground water beneath the site.

In wells 701, 702, and 703 the average total dissolved solids (TDS) concentrations for each well were 20,300,20,400 and 10,900 milligrams per liter (mg/L) respectively. In all three wells, the high TDS is due primarily to high levels of sodium chloride in the ground waters.

Median levels of barium exceeded the U.S. Environmental Protection Agency (EPA) MCL in wells 701, 702, and 703 and tended to increase as water levels in the wells increased. Median levels of selenium exceeded the EPA MCL in the same three wells, though over the period of sampling, concentrations decreased to levels less than the MCL. Cadmium and lead slightly exceeded the EPA MCLs in a few samples from all three wells, though median concentrations were below the MCL. Median levels of chromium and molybdenum exceeded the EPA MCL $(0.1 \mathrm{mg} / \mathrm{L})$ in wells 702 and 703 . The average combined radium226 and -228 for samples from well 701 slightly exceeded the UMTRA MCL (5 picocuries per liter [pCi/L]). Based on these data, ground water in the Wasatch Formation beneath the disposal cell is of limited use and is not a potential source of drinking water because it contains more than $10,000 \mathrm{mg} / \mathrm{L}$ TDS and because ambient levels of barium, cadmium, chromium, lead, molybdenum, selenium and combined radium-226 and -228 have exceeded EPA MCLs (40 CFR Part 192).

\subsubsection{Hazardous constituents}

Analyses of tailings and tailings solutions (TAC, 1989), tailings leachates (Markos and Bush, 1983), and ground water samples from both the old and new Rifle sites (DOE, 1990; DOE, 1996 and TAC, 1996) were evaluated for hazardous constituents generally expected to be in or derived from the residual radioactive materials related to the uranium processing activities. After evaluating these existing data, the DOE identified the following hazardous constituents as being associated with the tailings source term. 
- alpha-BHC

- antimony

- arsenic

- barium

- benzolajanthracene

- benzolalpyrene

- beryllium

- cedmium

- chrysene

- chromium

- cobalt

- copper
- diethyl phthalate

- di-n-octylphthalate

- fluoranthene

- fluoride

- not gross alpha

- indeno(1,2,3-cd)pyrene

- methyl ethyl ketone

- lead

- molybdenum

- nickel

- nitrate

- pyrene
- radium-226 and -228

- selenium

- silver

- strontium

- tin

- toluene

- vanadium

- uranium

- zinc

- 2,4,5-TP (Silvex)

- 2,4-D

- 2,4,5-T

\subsection{GROUND WATER PROTECTION}

The ability of the disposal cell to protect ground water depends on its engineering features. The design of the disposal cell minimizes contaminant migration from the disposal cell into foundation materials. The disposal cell will meet established ground water protection requirements because:

1. The multicomponent disposal cell cover will allow for optimal limited infiltration of precipitation into the cell, thereby minimizing long-term leaching of hazardous components from the tailings.

2. Ground water quality beneath the Estes Gulch disposal site has been determined to be class III (limited use) (40 CFR Part 192.11 (e) (11)).

3. The Estes Gulch disposal site is geologically isolated from the uppermost aquifer by as much as $3800 \mathrm{ft}(1158 \mathrm{~m})$ of siltstones, shales, and sandstones of the Wasatch Formation. 


\subsection{SITE INSPECTIONS}

The DOE will conduct inspections of the Estes Gulch disposal site to detect progressive change caused by slow-acting natural processes and to identify potential problems before the need for extensive maintenance, repairs, or corrective action. Reports of events or conditions that have affected or potentially could affect the disposal site also will be investigated. The DOE will compare the findings from these inspections to initial baseline conditions to identify any changes over time and to provide a basis for future inspections, repairs, and corrective actions. This process is shown in Figures 3.1. Site inspections will be documented. After each inspection, the DOE will prepare a report for the NRC that records the findings of the inspection and clearly identifies any adverse impacts or threats to the disposal cell.

\subsection{INSPECTION FREQUENCY}

The DOE will inspect the Estes Gulch disposal site annually. The DOE may schedule more frequent inspections at any time should the need arise. For example, the DOE may schedule an separate inspection of site vegetation if the annual site inspection did not coincide with the general growing season. The DOE will notify the NRC of the inspection schedule.

\subsection{INSPECTION TEAM}

The inspection team will consist of a minimum of two inspectors qualified to inspect disposal cell integrity and make preliminary assessments of modifying processes that could adversely affect the disposal cell. A plant specialist may also participate in inspections to evaluate planned revegetation on the disposal site.

If any problems are observed that require more investigation, follow-up inspection teams will include one or more technical specialists in appropriate disciplines to assess the problem(s) under investigation will be assembled. For example, a follow-up inspection by a plant specialist may be required to evaluate reports of significant plant growth on the rock cover, or a soils scientist or geomorphologist may be needed to evaluate erosion processes.

\subsection{SITE INSPECTION PROCEDURES}

Before each inspection, inspectors will perform a readiness review. The long-term surveillance program guidance (DOE, 1996) contains information useful in preparing for inspections.

Site inspections will cover the disposal cell, the surrounding disposal site area, and the immediate off-site areas. Site inspections must be thorough enough to identify any significant changes or active modifying processes that could potentially adversely affect the disposal cell. Surveillance should be performed to identify unanticipated effects of modifying processes such as gully formation, slope erosion, changes to the rock cover, 


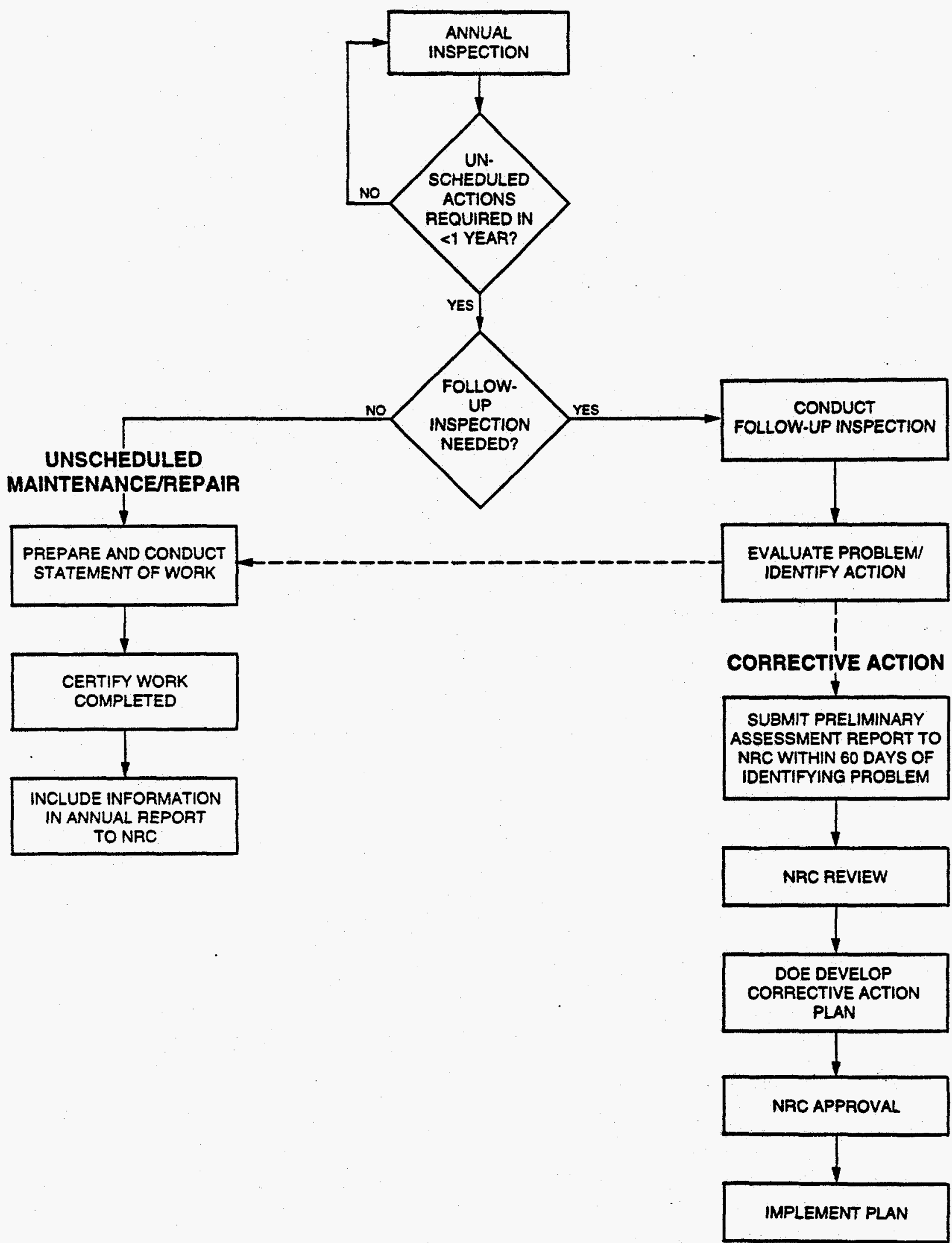

FIGURE 3.1

STEPS FOR FOLLOW-UP INSPECTIONS,

CUSTODIAL MAINTENANCE, AND CORRECTIVE ACTION ESTES GULCH DISPOSAL SITE 
ephemeral drainage channel changes, and significant modifications by humans, animals, or plants.

Inspectors will evaluate the integrity of the disposal cell by walking a series of transects around the perimeter and over the rock cover. Sufficient transects, at approximately 150$\mathrm{ft}(46-\mathrm{m})$ intervals, must be walked so that the disposal cell is thoroughly covered and inspected. Diagonal transects of the topslopes will be made and the crest line will be walked. Additional transects will be walked along the sideslopes and rock apron. Transects along the entire length of the diversion ditch will be made to determine whether it is functioning as designed and can be expected to continue to function properly. Inspectors will review transect paths from previous inspections and make efforts to vary the path of transects from one inspection to the next to ensure small anomalies are not overlooked. The sample inspection checklist in the LTSP guidance document (DOE, 1996) lists items that should be examined during inspections.

The disposal cell has a rock cover and there is no planned vegetation on the disposal cell. However, remedial action of the areas surrounding the disposal cell included revegetation with grasses. The area surrounding the disposal cell will be monitored to determine the success of the revegetation efforts. Inspectors also will inspect this area for evidence of erosion caused by wind, sheet wash, or changes in drainage patterns.

Site inspections also will monitor damage to or disturbance of permanent site-surveillance features, ground water monitor wells (until they are decommissioned), fencing, gate, and locks.

From inside the disposal site, inspectors will visually survey the area within a maximum of $0.25 \mathrm{mi}(0.40 \mathrm{~km})$ from the boundary of the disposal site for evidence of land-use changes that indicate increased human activity, such as land development or new roads and paths. Inspectors will note the condition of and changes to site access roads, surrounding vegetation, and relevant geomorphic features, such as gullies or ephemeral drainage channels; potential impacts to the site will be noted. Off-site DOE monitor wells will be inspected until they are properly decommissioned.

All site inspections will be conducted in accordance with a DOE-approved safety and health plan.

\subsection{FOLLOW-UP INSPECTIONS}

DOE will conduct follow-up inspections to investigate and quantify specific problems found during a previous inspection, other DOE-initiated activity, or other confirmed reports of vandalism, intrusion, damage, or other significant threat to the disposal site. Notifications of severe rainstorms, flash floods, or unusual events such as tornadoes or earthquakes in the vicinity of the Estes Gulch disposal site also can trigger follow-up inspections. Followup inspections will be conducted to determine whether processes currently active at or near the site threaten site security or stability and to evaluate the need for custodial maintenance, repair, or other corrective action. The scope of these follow-up inspections may be broad and similar in nature to routine site inspections or focused on specific areas of concern. 
A follow-up inspection usually will begin with an on-site visit by technical specialists to further investigate the reported problem and to determine the need for more definitive tests or studies. The DOE will schedule additional site visits if more data are needed to draw conclusions and to recommend repairs or corrective action.

\subsection{QUALITY ASSURANCE}

The DOE has developed and implemented a quality assurance plan (DOE, 1992C) for the site inspection program that meets the requirements of DOE Order 5700.6C. All site inspections will be conducted in accordance with this quality assurance plan.

\subsection{SITE INSPECTION DOCUMENTATION}

During site inspections, all activities and observations will be recorded and described using a site inspection checklist, site inspection map, photographs and photo log, and field notes. Documentary evidence of anomalous, new, or unexpected conditions or situations must describe developing trends and enable the DOE to make decisions concerning followup inspections, custodial maintenance, and corrective action. The DOE will prepare a site inspection report documenting the findings and recommendations from each field inspection.

\subsubsection{Site inspection checklist}

The sample site inspection checklist (DOE, 1996) is a guide for the inspectors to prepare for and conduct site inspections. Inspectors will prepare a site-specific checklist that addresses the features to be inspected and monitored at the Estes Gulch disposal site. All checklist items should be completed. Annotations should be made on the checklist to add more detailed information. All entries must be clearly stated and legible because the completed checklist becomes part of the permanent field record of the inspection. Upon completion of the inspection, the lead inspector must sign a statement certifying the scope of the inspection.

After each inspection is complete, the checklist may be revised, if necessary, to include new information or to delete items that are no longer pertinent. Revisions to the checklist will be documented in the inspection report.

\subsubsection{Site inspection maps}

Plate 1 will serve as the baseline for preparing the site inspection map. The inspection team will annotate copies of the site inspection map during site inspections. The ennotated site inspection map must include the following information:

- Inspection traverses.

- Photographic locations.

- Locations and descriptions of any new, anomalous, or unexpected features.

- Features identified during previous inspections for observation or monitoring. 
- Inspection date and type of inspection.

\subsubsection{Site inspection photographs}

A photographic record of the site inspection must be maintained. Site conditions should be documented by ground photographs to record developing trends and to enable the DOE to make decisions concerning additional inspections, custodial maintenance or repairs, or corrective action. If possible, any site feature or condition requiring inspectors to make a written comment, explanation, or description will be photographed. A site inspection photo log will be used to record the photographs. A separate photo log should be completed for each roll of exposed film, with an entry for each photograph.

At a minimum, the site features listed in the long-term surveillance guidance (DOE, 1996) should be documented with photographs during site inspections. In addition, any new or potential problem areas identified during a site inspection must be well documented with photographs. All site inspection photographs, as well as all corresponding photo log forms, will be maintained in the permanent site file.

\subsubsection{Field notes}

The inspection team will use field notes to record observations made during the inspection but not recorded on the inspection checklist or inspection map. The field notes will become part of the permanent site file.

\subsubsection{Site inspection report}

After every site inspection, the DOE will prepare a site inspection report that discusses scope of the inspection, observations made, and conclusions drawn from the inspection. At a minimum, the inspection report will include

- Description of the site conditions.

- Completed site inspection checklists and any relevant supporting documentation, including names and qualifications of the field inspectors.

- Site inspection map and other relevant drawings, maps, or figures.

- Inspection photographs and photo logs.

- Conclusions and recommendations for follow-up inspections, custodial maintenance, or repairs, if required.

- Custodial maintenance or repair report and certification, was performed.

If new conditions requiring monitoring or immediate action are discovered during the inspection, the inspection report will detail any observed modifying features and will include a description of the problem, relevant measurements and photographs, and an 
impact assessment. The description of the modifying process will include information such as the following:

- Extent of area affected.

- Number, spacing, and size of features (e.g., gullies).

- Locations and patterns of occurrence.

- Species, location, and density of volunteer plant growth.

Evidence of deliberate and repeated human intrusion such as cover removal, extensive vandalism to signs and monuments, or the presence of well-established trails will be described in detail. All signs of vandalism will be noted since evidence of continued vandalism may indicate the need to implement more active measures to control site access.

The results of all follow-up inspections shall be documented in written reports. Other appropriate documentation, such as photographs, measurements, and drawings, shall be included. At a minimum, a follow-up inspection report must include the following:

- Description of the problem and preliminary assessment of impact.

- Conclusions and recommendations for custodial maintenance, repair, or corrective action required.

- Assessment data, photographs, and supporting documentation.

A copy of all site inspection reports and supporting documentation will be maintained in the permanent site file. 


\subsection{GROUND WATER MONITORING}

The DOE evaluated the need for ground water monitoring at the Estes Gulch disposal site in accordance with the licensing regulations in 10 CFR $\$ 40.27(b)(2)$, the ground water protection standards in 40 CFR Part 192, Subparts A and C, and the DOE's long-term surveillance program guidance (DOE, 1996). POC monitoring is not required for the longterm surveillance program at the Estes Gulch disposal site.

\subsection{GROUND WATER MONITORING PLAN}

No routine ground water monitoring of the uppermost aquifer at the Estes Gulch disposal cell is required. Postclosure monitoring of ground water in the uppermost aquifer (Williams Fork Formation) is not proposed due to class III (limited use) (40 CFR Part 192.11 (e) (11)) designation of ground water in the Wasatch formation and due to the Wasatch Formation's considerable thickness (projected to be approximately $3,800 \mathrm{ft}(1,158 \mathrm{~m})$. Limited use ground water is ground water that is not a current or potential source of drinking water because 1$)$ the TDS concentration exceeds 10,000 (mg/L); 2) widespread ambient contamination exists unrelated to processing activities, and the contamination cannot be cleaned up using treatment methods reasonably employed in public water supply systems; or 3 ) the quantity of water available is less than $150 \mathrm{gal}(570 \mathrm{~L})$ per day. 


\subsection{CUSTODIAL MAINTENANCE AND REPAIR}

The DOE does not plan to conduct routine maintenance at the Estes Gulch disposal site. However, the DOE will perform needed custodial maintenance or repair as determined from site inspections. The DOE will prepare a statement of work that will include qualifications of the maintenance/repair contractor and certify all custodial maintenance and repair work performed at the Estes Gulch disposal site.

Unscheduled custodial maintenance or repair required at the Estes Gulch disposal site may be identified during an annual inspection. These repairs may include the following:

- Repairing or replacing deteriorated or vandalized warning signs, fencing, gates, and locks.

- Removing volunteer plant growth from riprap-covered areas.

- Reseeding areas surrounding the disposal cell.

If the repairs can be made without a follow-up inspection, a statement of work will be prepared.

After the work is completed, the maintenance/repair contractor must submit written verification of the completed work. The DOE will inspect the site, as necessary, and review the report before certifying that all work is completed in accordance with all required specifications.

The annual report to the NRC must include the following information on unscheduled maintenance or repair:

- Work order, purchase order, or statement of work.

- Contractor documentation of work completion.

- DOE certification of work completion.

Copies of all records, reports, and certifications will be included in the permanent site file. 


\subsection{CORRECTIVE ACTION}

If repairs are needed to address problems that may affect the integrity of the disposal cell or compliance with 40 CFR Part 192, the NRC must approve the recommended action in advance. Such action will be treated as a corrective action (see Section 6.0).

Site inspections are designed to identify problems at the developmental stage. Examples of conditions that might trigger corrective action are as follows:

- Surface rupture or subsidence of the disposal cell.

- Development of rills or gullies or slope instability on the disposal cell.

- Deterioration of the erosion protection rock on the disposal cell.

- Seepage originating from the disposal cell.

- Gully development on or immediately adjacent to disposal site property that could affect the integrity of the disposal cell.

- Damage to the cell cover or disposal site property from natural catastrophic events or vandalism.

- Evidence of hazardous material spills near monitor wells. .

- Damage to the disposal cell cover from deep-rooted plant growth.

If conditions such as these are observed during an annual inspection, a follow-up inspection will be conducted.

The DOE will evaluate the factors that caused the problem and identify actions to mitigate the impact and prevent recurrence by:

- Identifying the nature and extent of the problem.

- Reevaluating germane engineering design parameters.

If a problem requires more than maintenance described in Section 5.0, the DOE will submit a preliminary assessment report to the NRC for review no more than 60 days after the problem is identified. The preliminary assessment report will evaluate the problem and recommend the next step (e.g.. immediate action or continued evaluation). After the NRC reviews the report and recommendations, the DOE will develop a corrective action plan for NRC approval. Once the NRC approves the corrective action, the DOE will implement the plan. In some cases, corrective action could include temporary emergency measures taken prior to the completion of the normal approval process. 
NRC regulations do not stipulate a time frame for implementing corrective action (except in the case of finding of an exceedance in established ground water concentration limits, which is not applicable to this site.) The DOE does not consider assessing the extent of a problem and developing a corrective action plan to be initiation of the corrective action program.

In addition to the preliminary assessment report, the DOE may prepare progress reports on each corrective action while it is under way or under evaluation.

After corrective action is complete, the DOE will certify all work and submit a certification statement and supporting documentation to the NRC for review and concurrence. A copy of the certification statement will become part of the permanent site file, as will all reports, data, and documentation generated during the corrective action. 


\subsection{EMERGENCY NOTIFICATION AND RESPONSE}

To ensure the timely investigation of potential problems affecting the disposal cell, the DOE has requested notification from federal, state, and local agencies of discoveries or reports of any purposeful intrusion or damage at the disposal site, as well as the occurrence of earthquakes, tornadoes, or floods in the disposal site area.

The DOE is negotiating notification agreements with the Garfield County Sheriff's Office, the U.S. Geological Survey's National Earthquake Information Center, and the Colorado area office of the National Weather Service (Attachment 3). These agreements will trigger notification of the more probable occurrences that could cause an emergency response. In addition, the DOE 24-hour phone number is posted on the site entrance sign so the public can notify the DOE if problems are discovered.

The nature of the occurrence and the amount of first-hand knowledge available will determine the DOE's response. If an emergency situation poses an immediate threat to the public, the DOE will notify individuals who may be affected and appropriate federal, state, and local egencies, including the NRC. The DOE will take appropriate response action and advise the affected individuals of precautions that should be taken.

In all cases, the notification, response, and any follow-up activities shall be documented. This documentation will become part of the permanent site file. Discussions of emergency notifications and responses also will be included in the annual site report to the NRC. 


\subsection{RECORD KEEPING AND REPORTING}

The DOE will maintain a permanent site file containing site inspection reports and other supporting documentation of long-term surveillance program activities. The information placed in the site file will include:

- Documentation of disposal site integrity.

- Demonstration that licensing provisions were met.

- Information needed to forecast future site surveillance and monitoring needs.

- Reports to stakeholders regarding disposal cell integrity.

After the site is brought under the general license, the DOE will compile copies of site documentation required by the long-term surveillance program guidance (DOE, 1996) for the Estes Gulch disposal site permanent site file. Copies of all deeds, custody agreements, and other property documents will be kept in the site file.

The surveillance and maintenance documentation identified in other sections of this LTSP will be maintained by the DOE and become part of the permanent site file. The DOE will update the site file as necessary after disposal site inspections, maintenance activities, or corrective actions are complete. These records will be handled in accordance with DOE directives to ensure their proper handling, maintenance, and disposition. The archival procedures set forth in 41 CFR Part 101 and 36 CFR Parts 1220-1238 (Subchapter B) will be followed. All information will be available for NRC and public review.

The DOE will prepare an annual report documenting the results of site inspections and any other activities conducted in conjunction with the long-term surveillance program (Section 3.6.5). In accordance with 10 CFR Part 40 requirements, the annual report will be submitted to the NRC no more than 90 days after the date of the last UMTRA Project site inspection for that calendar year. This submittal will also include reports on any follow-up inspections and custodial maintenance or repairs performed during the year.

Following any inspection where unusual damage or disruption is discovered at the Estes Gulch disposal site; a preliminary report assessing the impact must be submitted to the NRC within 60 days of the initial discovery of the problem. If maintenance or repair or corrective action is warranted, the DOE will notify the NRC. The NRC will receive a copy of corrective action plans and each corrective action progress report, or the reports will be attached to the annual report.

The DOE will provide copies of inspection reports and other reports generated under the long-term surveillance program to the state of Colorado, as dictated in their cooperative agreement. 


\subsection{REFERENCES}

Coffin et al. (D. L. Coffin, F. A. Welder, and R. K. Glanzman), 1971. Geohydrology of the Piceance Creek Basin Between the White and Colorado Rivers, Northwestern Colorado, U.S. Geological Survey, Hydrologic Investigations Atlas HA-370, United States Geological Survey.

Coffin et al. (D. L. Coffin, F. A. Welder, and R. K. Glanzman), 1968. Geohydrologic Data From the Piceance Creek Basin Between the White and Colorado Rivers, Northwestern Colorado, U.S. Geological Survey Circular 12, Ground-Water Series, prepared by the United States Geological Survey in cooperation with the Colorado Water Conservation Board, Denver, Colorado.

Davis, S. N., and R. DeWiest, 1966. Hydrology, John Wiley \& Sons, Inc., New York, New York.

DOE (U.S. Department of Energy), 1996a. Guidance for Implementing the Long-Term Surveillance Program for UMTRA Project Title I Disposal Sites, DOE/AL-62350-189, Rev. O, prepared for the U.S. Department of Energy. Environmental Restoration Division, UMTRA Project Team, Albuquerque, New Mexico.

DOE (U.S. Department of Energy), 1996b. Long-Term Surveillance Plan - Part / Subcontract Documents RFL-LTSP-I, Final Design for Review, prepared for the U.S. Department of Energy, UMTRA Project Office, Albuquerque, New Mexico.

DOE (U.S. Department of Energy), 1994. Baseline Risk Assessment of Ground Water Contamination at the Uranium Mill Tailings Site Near Rifle, Colorado, DOE/AL62350-179, Rev. 2, prepared for the U.S. Department of Energy, UMTRA Project Office, Albuquerque Operations Office, Albuquerque, New Mexico.

DOE (U.S. Department of Energy), 1992a. Environmental Impact Statement of Remedial Action at the Former Union Carbide Corporation Uranium Mill Sites Rifle, Garfield County, Colorado DOE/EIS-0132, prepared for the U.S. Department of Energy, UMTRA Project Office, Albuquerque Operations Office, Albuquerque, New Mexico.

DOE (U.S. Department of Energy), 1992b. Remedial Action Plan for Stabilization of the Inactive Uranium Mill Tailings Site at Rifle, Colorado, UMTRA-DOE/AL050506.0000, prepared for the U.S. Department of Energy, UMTRA Project Office, Albuquerque Operations Office, Albuquerque, New Mexico.

DOE (U.S. Department of Energy), 1992c. Long-Term Surveillance and Maintenance Program Quality Assurance Program Plan, P.GJPO-152, prepared by Chem Nuclear Geotech, Inc., for the U.S. Department of Energy, Grand Junction Project Office, Grand Junction, Colorado.

DOE (U.S. Department of Energy), 1992. Remedial Action Plan and Site Design for Stabilization of Inactive Uranium Mill Tailings Sites at Rifle, Colorado. DOE/AL- 
050506, February 1992, Appendices D and E, prepared by the U.S. Department of Energy, UMTRA Project Office, Albuquerque Operations Office, Albuquerque, New Mexico.

DOE (U.S. Department of Energy), 1990. Remedial Actions at the Former Union Carbide Corporation Uranium Mill Sites, Rifle, Garfield County, Colorado, Final Environmental Impact Statement, Volume II: Appendices, DOE/EIS-0132-F, prepared by the U.S. Department of Energy, UMTRA Project Office, Albuquerque Operations Office, Albuquerque, New Mexico.

DOE (U.S. Department of Energy), 1987. "Draft Environmental Impact Assessment of Remedial Actions at the Former Union Carbide Corporation Uranium Mill Sites at Rifle, Garfield County, Colorado*, U.S. Department of Energy. UMTRA Project Office, Albuquerque Operations Office, Albuquerque, New Mexico.

FBDU (Ford, Bacon, and Davis, Utah, Inc.), 1981. Engineering Assessment of Inactive Uranium Mill Tailings, New and Old Rifle Sites, Rifle, Colorado, report prepared by FBDU, Salt Lake City, Utah, for the U.S. Department of Energy, UMTRA Project Office, Albuquerque Operations Office, Albuquerque, New Mexico.

Freeze, R. A., and J. A. Cherry, 1979. Ground Water, Prentice-Hall, Inc., Englewood Cliffs, New Jersey.

Giles, T.F., 1980. Reconnaissance of Groundwater Resources in the Vicinity of Gunnison and Crested Butte, West-Central Colorado, USGS Open File 80-12, January.

Hill, S. R., 1989. Manager, Jacobs Engineering Group Inc., Albuquerque Operations Office, personal communication with M. Matthews, U.S. Department of Energy, Albuquerque Operations Office, Albuquerque, New Mexico, UPDCC File Location No. 0.2.2.38.41, Albuquerque, New Mexico, 8 November 1989.

Markos G., and K. J. Bush, 1983. Data for the Geochemical Investigation of UMTRAP Designated Sites at Rifle, Colorado, prepared by Geochemistry and Environmental Chemistry Research, Inc., Rapid City, South Dakota, for the U.S. Department of Energy, UMTRA Project Office, Albuquerque Operations Office, Albuquerque, New Mexico.

MK-ECE, 1996. MK-F draft completion report

TAC (Technical Assistance Contractor), 1996. "Data package for February 1996 Rifle, CO Sample Analysis", unpublished report prepared by the Technical Assistance Contractor, Albuquerque. New Mexico, for the U.S. Department of Energy, UMTRA Project Office, Albuquerque Operations Office, Albuquerque, New Mexico.

Tweto et al. (O. Tweto, R. H. Moench, and J. C. Reed, Jr.), 1978. "Geologic Map of the Leadville 1' $\times 2$ ' Quadrangle, Northwestern Colorado," U.S. Geological Survey Miscellaneous Series, Map 1-999, Washington, D.C. 
Wright Water Engineers, 1979. Garfield County water resource map, prepared by Wright Water Engineers, Glenwood Springs, Garfield County, Colorado.

Yeend, W. E., 1969. Quaternary Geology of the Grand and Battlement Mesas Area, Colorado, U.S. Geological Survey, Professional Paper 617, Washington, D.C.

\section{CODE OF FEDERAL REGULATIONS}

10 CFR Part 40, Domestic Licensing of Source Material, U.S. Nuclear Regulatory Commission.

36 CFR Parts 1220-1238, National Archives and Records, Subchapter B - Records Management, National Archives and Records Administration.

40 CFR Part 192, Health and Environmental Protection Standards for Uranium and Thorium Mill Tailings, U.S. Environmental Protection Agency.

41 CFR Part 101, Federal Property Management Regulations, General Services Administration.

\section{DOE ORDERS}

Order 5700.6C, Quality Assurance, 21 August 1991, U.S. Department of Energy, Washington, D.C.

\section{UNITED STATES CODE}

42 USC $\$ 7901$ et seq., Uranium Mill Tailings Radiation Control Act, 8 November 1978. 


\section{ATTACHMENT 1}

\section{SITE REAL ESTATE INFORMATION}




\section{ATTACHMENT 2}

\section{SITE REAL ESTATE INFORMATION}


itv urve
202 Railroad Avenue

Rifle, Colorado 81650

970-625-2331

Sharon J. Arp

Site Manager

Uranium Mill Tailings Remedial Action Team

Environmental Restoration Division

U.S. Department of Energy

2155 Louisiana Blvd., NE, Suite 4000

Albuquerque, NM 87110

Dear Ms. Arp:

This letter is to concus with the U.S. Department of Energy (DOE) request for notification as set forth in the DOE's letter dated July 30,1996 . As requested, this office will contact the DOE's Grand Junction Projects Office at (970) 248-6070 if any unusual event is observed or reported at the Estes Gulch disposal site located near Rifle, Colorado.

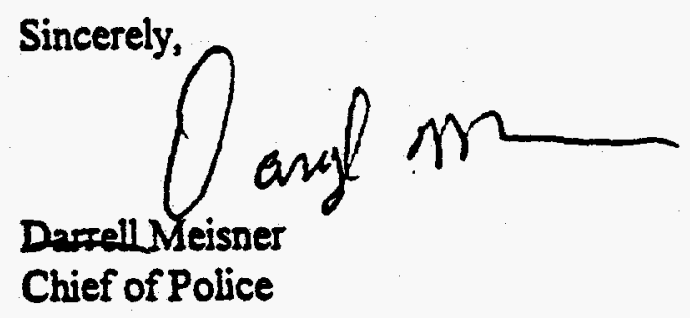


APPENDIX A

CLOSURE PLAN FOR MONITORING WELLS, ESTES GULCH DISPOSAL CELL 


\section{GENERAL}

\section{REAL ESTATE DOCUMENTATION}

The Uranium Mill Tailings Radiation Control Act (UMTRCA) of 1978, as amended, required the Secretary of Energy to permanently acquire lands needed to carry out the purposes of the UMTRCA. The U.S. Department of Energy (DOE) located the Rifle disposal site on public land administered by the U.S. Department of the Interior's Bureau of Land Management (BLM).

\section{JURISDICTIONAL TRANSFER OF THE DISPOSAL SITE}

Under the authority vested in the Secretary of the Interior by the UMTRCA, the BLM transferred administration of approximately 205 acres (83 hectares) of public land in Garfield County, Colorado, to the DOE. Publication in the Federal Register of Public Land Order (PLO) 6873 established the effective date of the transfer as August 28, 1991. As a result of this permanent transfer, the land is no longer subject to the operation of the general land laws, including mining and mineral leasing. The transfer vested in the DOE the full management, jurisdiction, and liability for the land and all activities conducted thereon.

\section{LEGAL DESCRIPTION}

The legal description contained in the PLO described the disposal site area as follows:

Township 5 South, Range 93 West, Sixth Principal Meridian.

Section 11: S1/2 S1/2 SW1/4 SW1/4 SE1/4; Section 14: NW1/4 NW1/4 NE1/4, W1/2 SW1/4 NW1/4 NE1/4, W1/2 W1/2 SW1/4 NE1/4, E1/2 NE1/4 NW1/4, E1/2 NW1/4 NE1/4 NW1/4, SW1/4 NE1/4 NW1/4, SE1/4 SE1/4 NW1/4 NW1/4, NE1/4 NE1/4 SW1/4 NW1/4, S1/2 NE1/4 SW1/4 NW1/4, SE1/4 SW1/4 NW1/4, SE1/4 NW1/4, NE1/4 SW1/4, NE1/4 NW1/4 SW1/4, E1/2 E1/2 NW1/4 NW1/4 SW1/4, W1/2 NW1/4 SE1/4, and W1/2 W1/2 NW1/4 SE1/4, containing approximately 205 acres (83 hectares). 


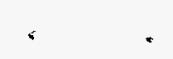




\section{A.1 DISPOSAL CELL TRANSIENT DRAINAGE MONITORING}

During design and analysis of the Rifle Disposal cell in 1990 and 1991, the UMTRA Project team and the NRC were concerned about transient drainage in the cell on the sloped Estes Gulch site. Specifically, there was a concern that transient drainage and surface infiltration might collect near the toe of the cell and build up excessively. If tailings drainage water were to build up above the rim of the excavation, a surface expression (i.e., seep) along the south slope of the disposal cell could inadvertently allow radionuclides to escape.

In the final remedial action plan (RAP. August 1991) for the Estes Gulch site, in Appendix $E$, on pages E-4 and E-5, transient drainage in the Rifle disposal cell is discussed. It was concluded in the RAP that to prevent a surface expression (i.e. seep), a temporary HDPE liner would be constructed inside the toe of the disposal cell, and that a temporary leachate collection system would be constructed.

The HDPE liner and a leachate collection system, consisting of three 18-inch-diameter monitor wells and a granular under-drain layer beneath the tailings, were installed during construction of the disposal cell (see MKF Rifle site construction drawings RFL-DS-100724, RFL-DS-10-0731 and RFL-DS-10-0732). For approximate locations of the monitor wells see Figure $A-1$.

The HDPE liner was designed and installed to prevent leachate seepage from the toe during the period of transient drainage from the cell. After transient drainage is completed (i.e., approximately one year after cell construction is completed), and steady state flow in the cell is established, the HDPE liner is not needed to prevent a seep. Although the liner is not needed for long term successful performance of the disposal cell, for the purposes of analyzing its affect on cell drainage, the liner was assumed to remain intact for 30 years.

Monitoring of leachate buildup in the cell began during construction in June of 1993 . Transient drainage water buildup was observed immediately in monitor well (MW) 2 and $M W-3$, but not in $M W-1$. MW-1 remained dry throughout construction, and has never (to this date, October 1996) showed any leachate buildup. This is because MW-1's bottom is at elevation 6021.4 feet, which is approximately 30 feet higher than bottom of MW- 2 and MW-3. MW-2 has been used as a primary indicator of the phreatic surface in the disposal cell, because it is closest to the bottom of the cell. Computer modeling (i.e. with the UNSAT2 program) has been done to correlate water levels at the toe of the cell to water levels recorded at MW-2. A plot of water levels in MW-2, after the last pumping, versus the computer modeled water level is included in Figure A-2.

UNSAT 2 computer modeling was performed to predict water levels in the monitor wells, predict long term water levels in the disposal cell, and predict when the monitor wells could be decommissioned. UNSAT2 modeling was performed and reviewed by DOE contractors, then submitted to CDPHE and NRC for review and concurrence. Since the Rifle cell was constructed at the Estes Gulch site, and not stabilized in place at the New or Old Rifle sites, test data recording moisture content, density, and consistency of the material compacted into the cell at thousands of known locations was available from 


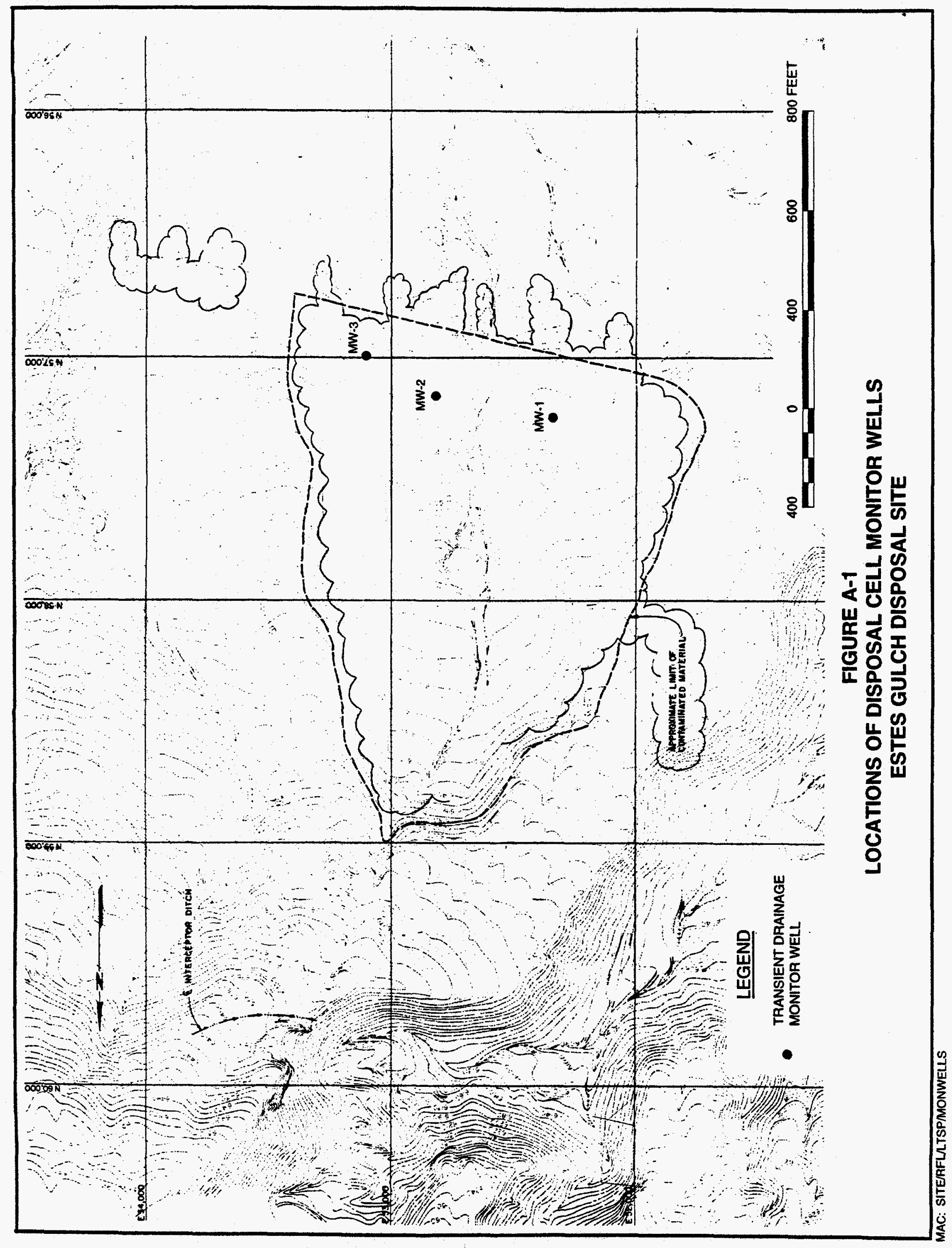




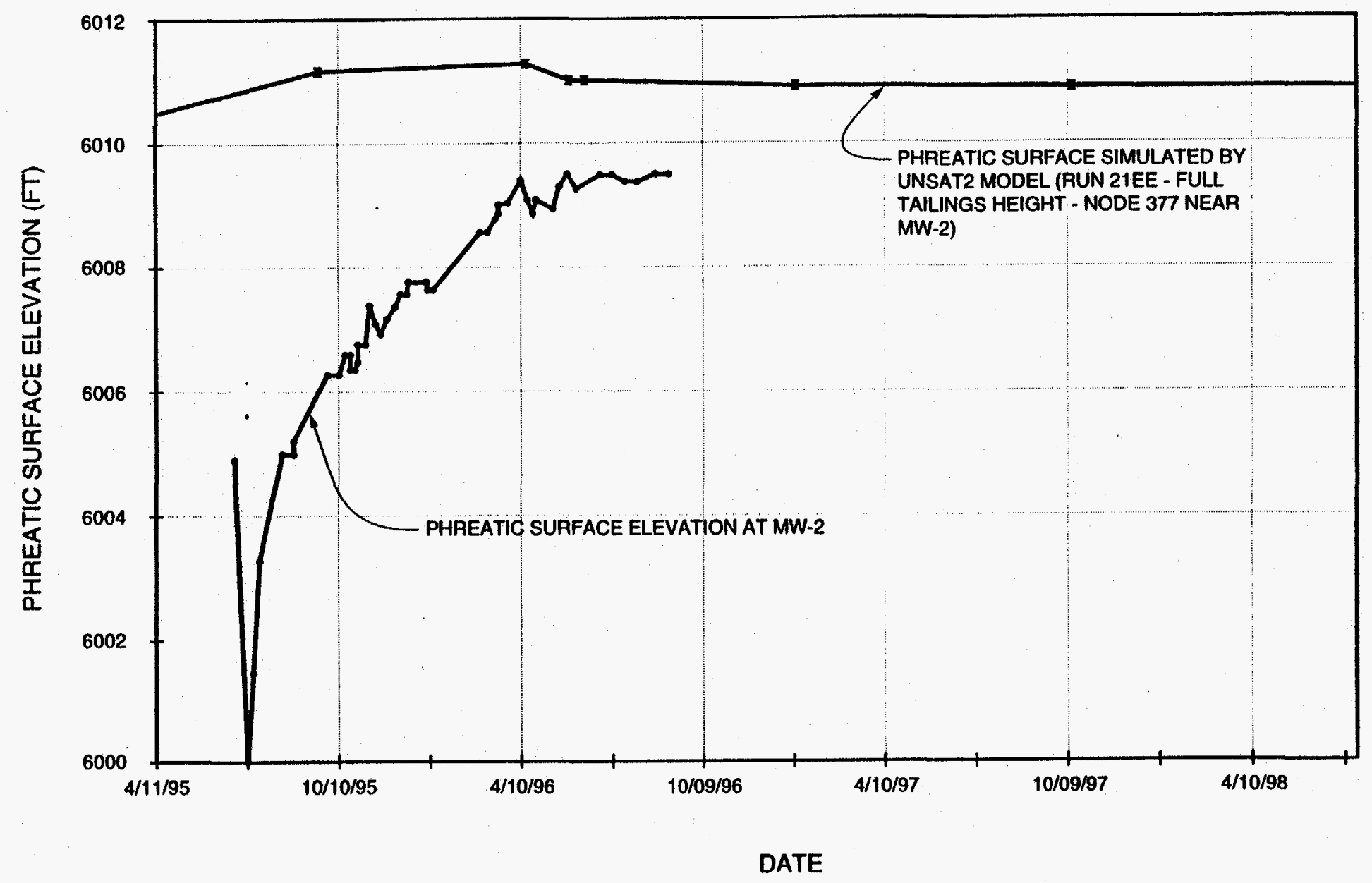

FIGURE A-2

MEASURED vS. PREDICTED LEACHATE LEVEL IN MW-2 ESTES GULCH DISPOSAL SITE 
quality assurance testing records. Results of the modeling were used to predict water levels in the cell during construction, and then actual water level measurements were used to check and adjust the model. Finally, after the model was adjusted to accurately reflect known water level versus time data, it was used to predict future water levels in the Rifle cell. Final results of the computer modeling indicated that the Estes Gulch cell would perform as designed, and that a seep at the toe of the cell from internal buildup of transient drainage would not occur. Results of the computer modeling work for the Rifle disposal cell are included in MK Ferguson's report "UNSAT2 MODELING FOR MONITORING WELL CLOSURE, ESTES GULCH DISPOSAL CELL, RIFLE COLORADO, NOVEMBER 1995," MK document number 3885-RFL-R-01-05671-01, dated November 3 , 1995.

A Rifle disposal cell monitor well closure plan was prepared. Monitoring and analysis required to determine when these wells can be decommissioned are included in MK Ferguson's final "OPERATION AND CONTINGENCY PLAN FOR MONITORING WELL CLOSURE, ESTES GULCH DISPOSAL CELL, SEPTEMBER 1996". A summary of the essential details of the monitor well closure plan is included in section 2.0 of this appendix. 


\section{A.2 MONITOR WELL CLOSURE PLAN}

Monitoring frequency, pumping of wells, and closure of wells at the Estes Gulch site depend upon leachate monitor level readings in monitor wells $M W-2$ and $M W-3$. Since the bottom of MW-1 is 5.4 feet above the action water level, it is expected to remain dry through the entire monitoring period.

Results of UNSAT2 computer modeling indicate that transient drainage from the cell will stabilize within one year of completion of construction. For the sake of conservatism, a five year monitoring plan has been developed. Quarterly monitoring of the wells is required starting in September of 1996. Although manual water level readings may be used for the data collection, use of data loggers that record water levels four times daily are recommended to assist in evaluation of trends and seasonal variations.

Action water levels at MW-2 and MW-3 have been set at elevations 6014 and 6016 . None of the monitoring wells will be closed until all three of the wells show a water level less than elevation 6016 with a downward trend for four consecutive quarters. Trend analysis will be done using the nonparametric Mann-Kendall test. Even if all three wells meet the closure criterion in the second or third year of monitoring, closure will not occur, and monitoring will continue until a full five-year period has elapsed. After the five year period of monitoring is completed, and trend analysis indicates that the water levels are decreasing, monitoring well closure work will be initiated.

If at any time during the monitoring period, the water level in MW-2 or MW-3 exceed elevation 6016, pumping will be initiated to lower the water level below elevation 6014. For details of the monitoring criterion, see the operation flowchart in Figure A-3. If pumping of monitoring wells is required, the water that is pumped from the wells will have to be collected in a retention basin, and spray evaporated. A plan for the retention basin and spray evaporation system is discussed in MK Ferguson's report no. 3885-RFL-R-0105670-02, "OPERATION AND CONTINGENCY PLAN FOR MONITORING WELL CLOSURE, ESTES GULCH DISPOSAL CELL, SEPTEMBER 1996." 


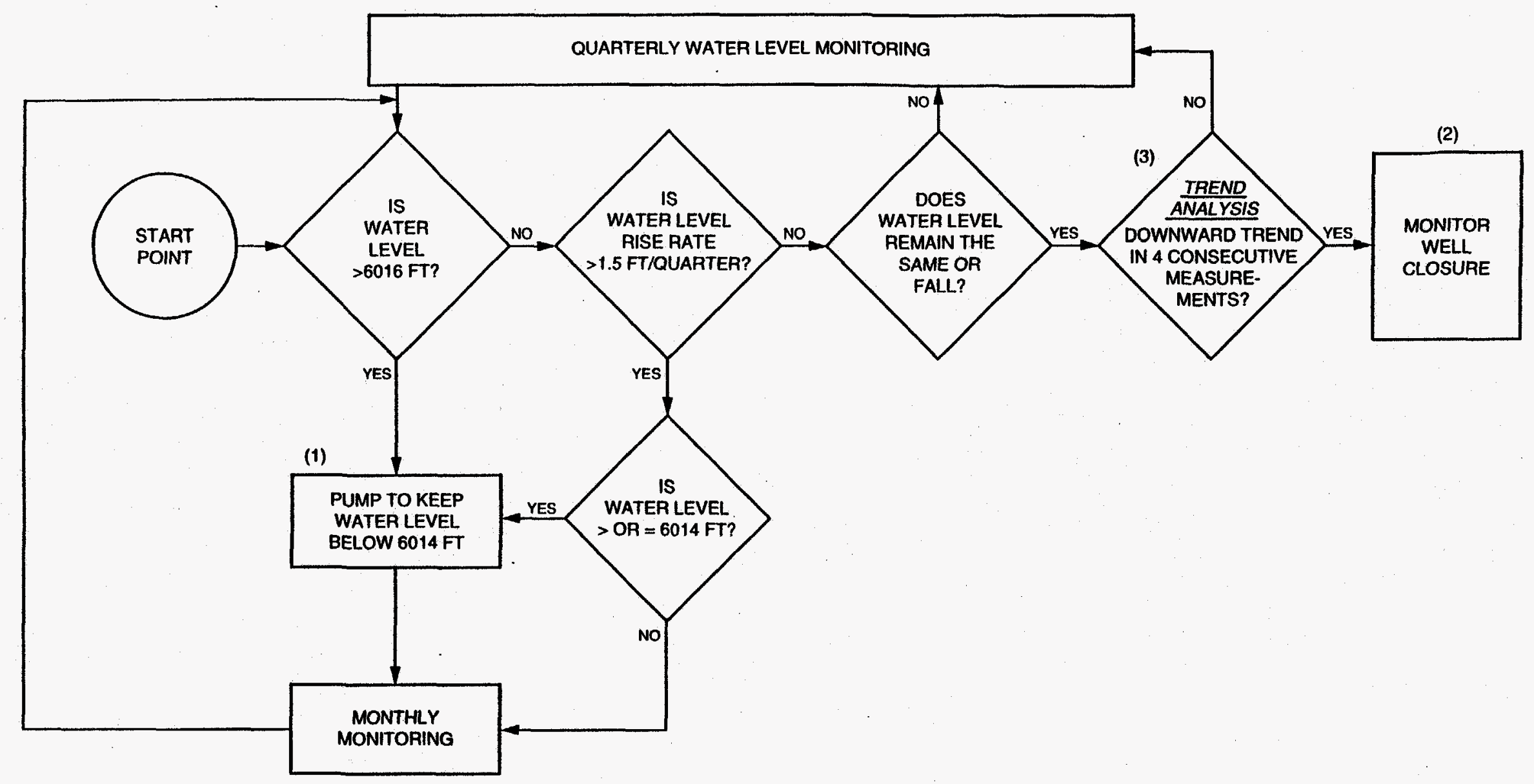

(1) PUMP INTERMITTENTLY AS REQUIRED TO KEEP WATER LEVEL UNDER $6014 \mathrm{FT}$ FOR ABOUT 90 DAYS AND MONITOR WATER LEVEL AT 2-DAY INTERVALS FOR 8 DAYS TO ENSURE WATER LEVEL IS BELOW 6014 FT UNDER NO PUMPING CONDITION.

(2) NO WELL WILL BE CLOSED UNLESS ALL THAEE WELLS SATISFY THE CLOSURE REQUIREMENTS. EVEN THOUGH THE CLOSURE CRITERIA MAY BE REACHED, THE MONITOR WELL WILL NOT BE CLOSED UNTIL THE FULL FIVE YEARS OF MONITORING IS COMPLETED.

(3) BASED ON TREND ANALYSIS.

FIGURE A-3

FLOWCHART OF FIELD ACTIVITIES AT MW-1, MW-2, AND MW-3

(SEPTEMBER 1996 - AUGUST 2001)

ESTES GULCH DISPOSAL SITE 